\title{
The role of CD27 in anti-viral T-cell immunity
}

Emma J. Grant ${ }^{1,2^{*}}$, Simone Nüssing ${ }^{1 *}$, Sneha Sant ${ }^{1}$, E Bridie Clemens ${ }^{1 \#}$ and Katherine Kedzierska $^{1 \#}$

${ }^{1}$ Department of Microbiology and Immunology, at the Peter Doherty Institute for Infection and Immunity, The University of Melbourne, Melbourne 3000, VIC, Australia; ${ }^{2}$ Institute of Infection and Immunity, Cardiff University School of Medicine, Heath Park, Cardiff CF14 4XN, United Kingdom; *equal contribution; \# equal contribution.

To whom correspondence should be addressed:

\#Katherine Kedzierska, kkedz@unimelb.edu.au, Department of Microbiology and Immunology, University of Melbourne, Vic 3010, Australia, Ph: (613) 83447962. 


\section{Abstract}

CD27 is a co-stimulatory immune-checkpoint receptor, constitutively expressed on a broad range of T-cells ( $\alpha \beta$ and $\gamma \delta$ ), NK cells and B-cells. Ligation of CD27 with CD70 results in potent co-stimulatory effects. In mice, co-stimulation of CD8 ${ }^{+}$T-cells through CD27 promotes immune activation and enhances primary, secondary, memory and recall responses towards viral infections. Limited in vitro human studies support mouse experiments and show that CD27 co-stimulation enhances antiviral Tcell immunity. Given the potent co-stimulatory effects of CD27, manipulating CD27 signalling is of interest for viral, autoimmune and anti-tumour immunotherapies. This review focuses on the role of CD27 co-stimulation in anti-viral T-cell immunity and discusses clinical studies utilising CD27 co-stimulation pathway for anti-viral, antitumour and autoimmune immunotherapy.

\section{Keywords:}

CD27, CD70, anti-viral immunity, co-stimulation, T-cells, immunotherapy 


\section{Introduction}

CD27 is a receptor of the tumor necrosis factor (TNF) superfamily, expressed on a broad range of lymphocytes, including T-cells ( $\alpha \beta$ and $\gamma \delta$ ) [1-3], B-cells [4-6] and natural killer (NK)-cells [7,8]. In T-cells, binding of CD27 to its ligand CD70 results in activation of both canonical and alternative NFKB pathways $[9,10]$ that mediate signalling and downstream co-stimulatory effects and provide potent enhancement of T-cell responses [11,12]. CD27 co-stimulation promotes immune responses and enhances primary, secondary, memory and recall $\mathrm{CD} 8^{+} \mathrm{T}$-cell responses towards acute viral infections in murine models $[10,13]$. However, the role of CD27 in human lymphocytes is understudied. Due to its strong co-stimulatory effects, the CD27/CD70 pathway has recently gained interest as an immunotherapeutic target for anti-viral immunity. Manipulation of this pathway may also be beneficial for the control of autoimmune diseases or tumour immunotherapy. This review summarizes the impact of CD27 co-stimulation in anti-viral T-cell immunity and discusses its potential for immunotherapies.

\section{CD27 expression and its potent role in T-cell activation}

\section{(i) Optimal T-cell activation requires 3 signals}

Following thymic selection, naive circulating T-cells survey for foreign antigens displayed by professional antigen presenting cells (APCs), mainly dendritic cells (DCs) [14]. During infection, DCs acquire antigens, either through direct infection or uptake of material from infected tissues, become activated and migrate to secondary lymphoid tissues where they present pathogen-derived peptides to circulating T-cells. DCs typically require an initial interaction with antigen-specific helper $\mathrm{CD} 4^{+} \mathrm{T}$-cells $[15,16]$ before they are licensed to activate naïve $\mathrm{CD} 8^{+} \mathrm{T}$-cells $\left.[16,17]\right)$. Effective activation of naïve $\mathrm{CD} 8^{+} \mathrm{T}$-cells by licensed $\mathrm{DCs}$ requires three distinct signals $[18,19]$. CD8 ${ }^{+}$T-cells recognize the pMHCI complex through use of their T-cell receptors (TCRs) to provide the first signal [20]. The second signal is provided by costimulation via the interaction of TNF-TNFR family receptors [21] and CD28CD80/86 [22] on the CD8 ${ }^{+}$T-cell and DCs [19,23]. Lastly, pro-inflammatory cytokines (mainly IL-12 and Type I IFN) present in the environment during priming provide a third signal that can influence subsequent T-cell differentiation pathways to ensure a productive response [24]. The presence of all three signals activates a 
cascade of signalling pathways, culminating in the activation and translocation of $\mathrm{NF \kappa B}$ to the nucleus of T-cells [25]. This induces T-cell proliferation and differentiation, resulting in the acquisition of effector functions and modification of cell surface markers, including cytokine/chemokine receptors and integrins that enable migration to the site of infection [26].

\section{(ii) The role of $C D 27$ co-stimulation in T-cell activation}

While studies to date have focused predominantly on co-stimulation via CD28, more recently the role of CD27 co-stimulation in T-cell activation has been acknowledged $[9,13]$. CD27, first characterised by van Lier et al [27] in 1987, is a co-stimulatory molecule in both mice [28] and humans [27,29]. It is a transmembrane homodimer of the TNFR family $[9,30,31]$, constitutively expressed on the surface of progenitor and naïve T-cells, as well as subsets of NK- and B-cells [9]. Its ligand, CD70, is inducible on APCs, DCs [32], B cells (triggered by TLR4/9, IFN $\gamma$ and CD40) and T-cells (following TCR interactions in the presence of CD28 cross-linking) and is constitutively expressed on smooth muscle cells [9]. Following the interaction between CD27 and CD70, TNFR-associated factor (TRAFs) adaptors are recruited [33], which then activate $\mathrm{CD} 8^{+} \mathrm{T}$-cells through both canonical and alternative $\mathrm{NF \kappa B}$ pathways $[9,10]$. The CD27-CD70 interaction also induces the up-regulation of antiapoptotic molecules (BCL-XL) [34] and cytokine receptors (IL-2R $\alpha$ and IL-12R $\beta$ ), thus increasing $\mathrm{CD} 8^{+} \mathrm{T}$-cell sensitivity to cytokines [9]. This interaction facilitates activation of JuN N-terminal kinase (JNK), activator protein 1 (Ap1), eRK and mitogen activated protein (MAP) kinases to promote cytokine production including: IL-2, IL-4, IL-5, IL-6, IL-12, IFN $\gamma$ and TNF $\alpha$ [9]. CD27 expression on T-cells increases following activation and is accompanied by release of a soluble extracellular part of the molecule [35]. Loss of CD27 expression on T-cells is observed during prolonged stimulation and is associated with fully a differentiated effector phenotype.

\section{CD27 co-stimulation enhances antiviral T-cell immunity}

Analyses in mice suggest that co-stimulation through CD27 is important during T-cell development [36], primary activation [11,37*-41], transition into memory $\left[11,37^{*}, 42\right]$, secondary recall and the long-term survival of T-cells [13,31] (summarised in Figure 1 and Table 1). Gravestein et al [36] observed CD27 
expression on thymocytes during the double negative (DN) stage of development and using $\mathrm{RAG}^{-/-}$mice showed that blocking CD27 co-stimulation with a mAb decreased the transition of DN to double positive (DP) thymocytes, thus revealing that CD27 costimulation is important in T-cell development.

\section{(i) CD27 co-stimulation enhances primary anti-viral CD ${ }^{+} T$-cell responses}

Published evidence reveals the importance of CD27 co-stimulation during primary viral infection (Table 1). Willoughby et al [37*] and Rowley et al [11] adoptively transferred OT-1 CD8 ${ }^{+}$T-cells into naïve mice and activated them with OVA peptide in the presence of a CD27-agonist antibody. Augmented CD27 co-stimulation increased the expansion of epitope-specific $\mathrm{CD} 8^{+} \mathrm{T}$-cells $\sim 50$-fold [37*], improved effector function and enhanced cytotoxicity in response to re-stimulation with peptide [11]. Similarly, using CD70-transgenic mice with constitutive CD70 expression on Tcells [41], CD27 co-stimulation resulted in a 2 -fold increase in the number and function of $\mathrm{D}^{\mathrm{b}} \mathrm{NP}_{366}{ }^{+} \mathrm{CD} 8^{+} \mathrm{T}$-cells and accelerated viral clearance following influenza A virus (IAV) infection. Conversely, in $\mathrm{CD} 27^{-/-}$mice, the number of total $\mathrm{D}^{\mathrm{b}} \mathrm{NP}_{366}{ }^{+} \mathrm{CD}^{+} \mathrm{T}$-cells was decreased in the lungs at 10 days after IAV infection [38]. Furthermore, T-cells isolated from $\mathrm{CD} 27^{-/-}$mice were less likely to proliferate compared to T-cells isolated from wild-type (WT) mice following anti-CD3 crosslinking in vitro. Interestingly, anti-CD28 co-stimulation augmented this proliferation, but not to WT levels, suggesting that CD27 and CD28 co-stimulation are not redundant and are qualitatively different. CD70 ${ }^{-/-}$mice infected with acute LCMV displayed a $<2$-fold decrease in total $\mathrm{D}^{\mathrm{b}} \mathrm{NP}_{396}{ }^{+} \mathrm{CD} 8^{+} \mathrm{T}$-cells 6-8 days post infection (dpi) and a $\sim 5$-fold reduction in viral clearance compared to WT mice [39*]. Similarly, $\mathrm{CD}^{+}$T-cells from WT mice infected with acute LCMV and treated with a blocking CD70 mAb [40] were less functional upon peptide re-simulation at 7dpi. Collectively, these studies demonstrate that CD27 co-stimulation is important for $\mathrm{CD}^{+} \mathrm{T}$-cell proliferation, cytotoxicity and function and enhances viral clearance during primary infection with acute IAV and LCMV.

\section{(ii) CD27 co-stimulation augments memory $C D 8^{+} T$-cell pools}

$\mathrm{CD} 27$ co-stimulation also increases the magnitude of memory epitope-specific $\mathrm{CD} 8^{+}$ T-cell populations. In adoptive transfer experiments with OT-1 $\mathrm{CD}^{+} \mathrm{T}$-cells, 
augmenting CD27 co-stimulation during priming increased the proportion of OT-1 $\mathrm{CD}^{+}$T-cells $>30$-fold at 23 days post-activation (dpa) [11]. Conversely, chronic $\mathrm{CD} 27$ co-stimulation decreased $\mathrm{NP}_{366}{ }^{+} \mathrm{CD}^{+}$T-cell numbers 4-fold 57dpi with IAV [41]. The increase in epitope-specific memory with CD27 co-stimulation is likely to result from enhanced IL-7 signalling, as augmentation of CD27 co-stimulation retains IL-7R $\alpha$ expression on $\mathrm{T}$ cells [37*], while blocking CD27 co-stimulation decreases IL-7R $\alpha$ expression [42]. IL-7, produced by non-hematopoietic cells (e.g. stromal and epithelial cells) and immune cells such as DCs (reviewed in [43]) is functionally important for memory cell development and survival [44]. In this way, CD27 costimulation increases sensitivity to IL-7 via IL-7R $\alpha$ expression and enhances epitopespecific $\mathrm{CD}^{+} \mathrm{T}$-cell transition into memory.

\section{(iii) $C D 8^{+} T$-cell recall is increased with $C D 27$ co-stimulation}

$\mathrm{CD} 27$ co-stimulation also enhances $\mathrm{CD}^{+} \mathrm{T}$-cell recall (Table 1). Blocking CD27 costimulation in $\mathrm{CD} 27^{-/-}$mice delayed $\mathrm{CD} 8^{+} \mathrm{T}$-cell recall following secondary IAV infection, with an early reduction in virus-specific $\mathrm{CD} 8^{+} \mathrm{T}$-cells observed 5dpi [38]. However, this difference was reduced by 7 dpi. Conversely, augmenting CD27 costimulation either during priming [11] or recall [45*] enhanced secondary responses by OT-I $\mathrm{CD}^{+} \mathrm{T}$ cells to OVA peptide. Interestingly, constitutive $\mathrm{CD} 27$ costimulation resulted in diminished $\mathrm{T}$ cell responses and impaired protection following secondary challenge with IAV [41]. These data show that enhanced, but not constitutive, CD27 co-stimulation during either primary or secondary infection can augment memory formation and recall responses.

\section{(iv) Effects of CD27 co-stimulation in humans}

Despite numerous murine studies, little is known about the role of CD27 costimulation in human T-cells (Table 2). In vitro findings show that augmenting CD27 co-stimulation by CD27 cross-linking [46,47**] or the addition of Colo679-CD70expressing cells [48] increased proliferation and function (IFN $\gamma / \mathrm{TNF}$ expression) of human T-cells 2- to 4-fold following non-specific activation [46,48]. Expectedly, gene expression profiling showed activation and proliferation profiles in T-cells with enhanced CD27 co-stimulation [47**]. Two independent studies also correlated the loss of CD27 co-stimulation with disease severity. A total of 8 patients with severe infectious mononucleosis (IM) and complications including EBV-associated 
proliferative disorder and HLH malignant lymphoma, had mutations in their CD27 gene $[49,50]$, resulting in loss of expression and thus CD27 co-stimulation. These studies suggest that CD27 co-stimulation is important in controlling chronic EBV infection and that CD27 co-stimulation has similar effects in mice and humans, and thus CD27 is important for effective activation of human $\mathrm{CD} 8^{+} \mathrm{T}$-cells.

\section{CD27 expression on $\gamma \delta$ T-cells, B-cells and NK-cells}

\section{(i) Expression of CD27 on murine and human $\gamma \delta T$-cells}

Recently, it became apparent that two functionally distinct subsets of $\gamma \delta$ T-cells display differential expression of CD27. Although both $\mathrm{CD} 27^{+}$and $\mathrm{CD} 27^{-}$subtypes produce IFN- $\gamma$, only $\mathrm{CD} 27^{-} \gamma \delta \mathrm{T}$-cells produce IL-17 following in vitro stimulation with phorbol 12-myristate 13-acetate (PMA) and ionomycin [1]. This effect of CD27 expression on $\gamma \delta$ T-cells was characterised on thymocytes derived from foetal organ thymic cultures (FTOC) and showed that $\mathrm{CD} 27^{+} \gamma \delta$ thymocytes had higher Ifng mRNA expression, while CD27 $\gamma \delta$ thymocytes had decreased $I l 17$ expression (Table 3). Furthermore, $\mathrm{CD}_{2} 7^{-} \gamma \delta$ T-cells isolated from the spleen, lymph nodes (LN), lung or gut were $\mathrm{CD} 44^{\mathrm{hi}}$ and $\mathrm{CD} 62 \mathrm{~L}^{\text {lo }}$, whereas $\mathrm{CD} 27^{+} \gamma \delta$ T-cells had lower CD44 expression, supporting CD27 as a marker of $\gamma \delta$ T-cell differentiation with distinct functional outcomes [1]. Lombes et al [3*] reported that innate-like IL-17-producing $\mathrm{CD} 27^{-} \gamma \delta$ T-cells correspond to Ly-6C CD $44^{\mathrm{hi}} \gamma \delta \mathrm{T}$-cells, as they proliferate in secondary lymphoid organs and thus have self-renewing, long-living properties.

The impact of the CD27 co-stimulatory pathway in peripheral $\gamma \delta$ T-cells remains largely unknown. Lombes et al [3*] suggested that peripheral $\mathrm{CD} 27^{+} \gamma \delta \mathrm{T}$ cells are similar to $\alpha \beta$ T-cells, by having distinct naïve-like and memory-like subsets with characteristic phenotypic, functional, and homeostatic outcomes, and as such, $\mathrm{CD} 27$ co-stimulation may affect the $\mathrm{CD} 27^{+} \gamma \delta \mathrm{T}$-cells in a similar manner. This was addressed by Ribot and colleagues [51], who stimulated murine $\mathrm{CD} 27^{+} \gamma \delta$ T-cells in vitro with $\mathrm{sCD} 70$ and showed increased IFN $\gamma / \mathrm{TNF}$ production with $\mathrm{CD} 27$ costimulation. Additionally, accumulation of IFN $\gamma$-producing $\mathrm{CD} 27^{+} \gamma \delta$ T-cells during MuHV-4 herpes or malaria infection was dependent on CD27 expression [51], emphasising the importance of CD27 for both anti-viral and anti-parasitic immunity (Table 3). Finally, to our knowledge, only one study has explored the co-stimulatory role of CD27 on human peripheral blood $\gamma \delta$ T-cells. deBarros et al [52] showed that 
interaction of CD27 with its ligand CD70 resulted in increased TCR-dependent production, establishing the importance of $\mathrm{CD} 27$ co-stimulation on the functional differentiation of human $\gamma 9 \delta 2$ T-cells (Table 3). Since $\gamma \delta$ T-cells contribute to antiviral and anti-cancer immunity, it is important to elucidate the role of CD27 costimulation and its potential role for future immunotherapies.

\section{(ii) CD27 as a memory B-cell marker}

Like T-cells, human B-cells can be subdivided according to their CD27 expression. However, unlike T-cells, naïve B-cells do not express CD27 and instead expression of $\mathrm{CD} 27$ is associated with memory. Interestingly, CD27 B-cells populate the nonmutated V gene compartment of naïve-like B-cells [4], while expression of CD27 $\left(\mathrm{CD} 27^{+}\right)$is commonly used to identify human memory B-cells with mutated $\mathrm{V}$ genes [4,5]. Circulating CD $27^{+}$memory B-cells can be further subdivided by their relative expression of the immunoglobulin (Ig) antibodies $\operatorname{IgM}$ and $\operatorname{IgD}[4,53]$. Up to $40 \%$ of human peripheral B-cells express CD27 and show mutated variable regions in their Ig genes [6], making the CD27 receptor an interesting marker for B-cell subsetting. However, a minor $\mathrm{CD} 27^{-}$memory B-cell subset makes up 1-4\% of all peripheral Bcells [6]. Therefore, CD27 expression alone is insufficient for B-cell memory identification. The function of CD27 co-stimulation on human memory B-cells has not been characterised, however, it is thought that, similar to T-cells, CD27-receptor signalling in B-cells can enhance survival [12]. It would be interesting to understand whether CD27 co-stimulation on B-cells is beneficial for maintaining lifelong serological memory by promoting the survival of memory B-cells. As such, determining the functional role of $\mathrm{CD} 27$ co-stimulation for B-cells may provide further potential for CD27-based immunotherapies.

\section{(iii) CD27 expression marks functionally distinct NK-cells}

NK-cells can also be sub-divided based on CD27 expression in both mice and humans $[7,8]$. In mice, the presence or absence of CD27 expression results in distinct effector functions, proliferative capacities, responsiveness, interaction with DCs, and migratory activity of NK-cells [7]. Mac $1^{\text {high }} \mathrm{CD} 27^{+}$murine NK-cells show increased IFN $\gamma$ production compared to $\mathrm{CD} 27^{-}$NK-cells following activation with the NKG2D 
ligand or IL-12 and IL-18. CD27 ${ }^{+}$NK-cells are predominately located in lymphoid or peripheral blood and represent long-lived or senescent NK-cells [7].

Accordingly, two subsets of NK-cells, based on CD27 expression, are found in humans [8]. The majority of circulating human peripheral blood NK-cells are $\mathrm{CD} 27^{-\mathrm{CD}} 56^{\mathrm{dim}}$, and express high levels of perforin and granzyme $\mathrm{B}$, however a subset of $\mathrm{CD} 27^{+} \mathrm{NK}$-cells are identified as CD56 ${ }^{\mathrm{dim} / \text { bright }}$ with low levels of perforin and granzyme B [8]. This suggests that, similar to T-cells, the presence or absence of CD27 on NK-cells allows the identification of cytotoxic effector cells within the known mature NK-cell subsets.

\section{Potential for manipulating CD27 co-stimulation for immunotherapy}

The potent co-stimulatory capacity of CD27 and its expression across different subsets makes the CD27/CD70 signalling pathway a desirable target for immunotherapy. Different strategies of blocking or augmenting CD27/CD70 costimulation and the resultant outcomes for acute or chronic viral infections, autoimmune diseases, tumours, are discussed.

\section{(i) Blocking CD27 co-stimulation may protect against immunopathology during} chronic viral infections or autoimmunity.

Although beneficial during acute infections, CD27 co-stimulation may be detrimental during autoimmune or chronic viral infections [10,31] (Table 4). Lymphocytes derived from patients with the autoimmune disease systemic lupus erythematosus (SLE) [54] or rheumatoid arthritis [55] have a 2-fold increase in CD70 expression on $\mathrm{CD} 4^{+}$T-cells, compared to healthy individuals. Since CD27 co-stimulation influences the production of pro-inflammatory cytokines, it might contribute to the pathology associated with inflammatory autoimmune diseases [10]. Indeed, SJL/J [56], DBA/1 [57] and $\mathrm{RAG}^{-/-}$[58] mice activated to induce disease in the absence of CD27stimulation had a reduction ( 4-times) in clinical scores [9,30], suggesting that CD27 co-stimulation might be detrimental during particular autoimmune diseases, and that blocking CD27 co-stimulation may be a feasible option for future autoimmune immunotherapies (Table 4). 
During chronic viral infections, T-cells become "exhausted" [59]. Strikingly, increased expression of CD70 and decreased CD27 expression was observed directly ex vivo on naïve $\mathrm{CD} 19^{+} \mathrm{CD} 27^{-} \mathrm{B}$-cells [60] and $\mathrm{CD}^{+}$T-cells [61] isolated from HIVinfected individuals compared to healthy donors, suggesting that prolonged CD27 costimulation may contribute to immunopathology during certain chronic infections. Using a transgenic mouse model with constitutive CD70 expression on T-cells to mimic the expression patterns observed in chronic infections, it was found that $\mathrm{CD}^{+}$ T-cells subjected to continuous CD27 co-stimulation displayed enhanced response magnitude to influenza infection compared to WT mice [41]. However, these cells exhibited an exhausted phenotype, as measured by CD69hi PD- $1{ }^{\text {hi }}$ IL $7 R^{\text {lo }}$ expression, and decreased IL-2/TNF production. Interestingly, CD70 blockade in mice during chronic LCMV (LC-13) infection increased numbers of IFN $\gamma$-producing virusspecific $\mathrm{CD}^{+}$T-cells, but did not alter their exhausted phenotype [40], and accelerated viral clearance [62]. Thus, uncontrolled CD27 co-stimulation deregulates effector $\mathrm{T}$ cell differentiation, promotes exhaustion and contributes to the detrimental outcomes of chronic infections [40,62]. CD27 co-stimulation thus requires careful regulation [10]. As such, there is emerging interest in blocking CD27 co-stimulation in chronic viral infections and inflammatory disease [9,31].

\section{(ii) Augmenting CD27 co-stimulation may help in cellular immunity to cancer}

CD70 is highly expressed in multiple cancers including thymic carcinoma [38], cultivated brain tumours [63] and renal carcinoma [64]. Hence, CD70 and CD27 are considered as targets for immunotherapy [31,65-68]. Augmenting CD27 costimulation through use of CD70-secreting or expressing tumour cells in mice has resulted in potent enhancement of cell-mediated anti-tumour immunity to reduce or prevent tumour development, even at locations distal to the treatment site $[69,70]$ (Table 5). This suggests that augmenting CD27 co-stimulation enhances systemic anti-tumour immunity and thus may be important for future immunotherapies. Indeed, a promising agonist anti-CD27 antibody is currently in phase I clinical trials. This immunotherapy, known as Varlilumab, is manufactured by Celldex Therapeutics and is being trialled against solid tumours and lymphoid malignancies [71] (Table 5). Although preliminary, this trial is highly promising and proves that manipulating CD27 co-stimulation may be an effective and viable anti-tumour immunotherapy, possibly in combination with other immunotherapies such as PD-1 blockade [72**]. 


\section{Conclusion}

CD27 is expressed on the majority of human T-cells and B-cells. Binding of CD27 to its only known ligand, CD70, has potent co-stimulatory effects, which can be either beneficial or detrimental in different circumstances. Due to these potent costimulatory effects, there is a great interest in manipulating CD27 co-stimulation for immunotherapy. Blocking CD27 co-stimulation may prevent/reduce the severity of chronic viral infections and autoimmune diseases. Conversely, augmenting CD27 costimulation may assist in anti-tumour immunity and may rescue exhausted $\mathrm{CD} 8^{+} \mathrm{T}$ cells. Thus, targeting and manipulating the CD27-CD70 immune pathway is an exciting and emerging field, with a great promise for novel immunotherapies.

\section{Acknowledgements}

This work was supported by Australian National Health and Medical Research Council (NHMRC) Program (AI1071916) Grant to KK. EJG is a recipient of a NHMRC CJ Martin Fellow, EBD is a NHMRC Peter Doherty Fellow and KK is an NHMRC SRF Level B. SN was supported by a Melbourne International Fee Remission Scholarship (MIFRS) and Melbourne International Research Scholarship (MIRS). SS was supported by a Victoria India Doctoral Scholarship (VIDS) and MIFRS.

\section{Figure Legend}

Figure 1. Effects of CD27 co-stimulation on naïve, effector, and memory $\mathrm{CD8}^{+} \mathrm{T}$ cells. CD27 co-stimulation of naïve $\mathrm{CD}^{+} \mathrm{T}$ cells via CD70 expressed on DCs or APCs leads to the activation of canonical and non-canonical NF- $\kappa$ B pathways, resulting in up-regulation of anti-apoptotic molecules and cytokine receptors. Augmented CD27 co-stimulation during primary activation increases a number of epitope-specific $\mathrm{CD}^{+} \mathrm{T}$ cells, enhanced effector function and retention of IL-7R $\alpha$ expression, thus elevating numbers of $\mathrm{CD}^{+} \mathrm{T}$ cells that persist into memory and participate in recall responses. Interestingly, chronic CD27 co-stimulation results in reduced $\mathrm{T}$ cell memory and impaired protection against subsequent virus infection. 
Diminished CD27 co-stimulation is associated with numerically and functionally reduced $\mathrm{CD}^{+} \mathrm{T}$ cell responses and decreased memory formation. Given these potent effects of $\mathrm{CD} 27$ co-stimulation on the magnitude and quality of $\mathrm{CD} 8^{+} \mathrm{T}$ cell immunity, manipulating CD27 signalling may prove an effective target of immunotherapies not just for viruses, but also chronic diseases and cancer.

\section{References}

1. Ribot JC, deBarros A, Pang DJ, Neves JF, Peperzak V, Roberts SJ, Girardi M, Borst $\mathrm{J}$, Hayday AC, Pennington DJ, et al.: CD27 is a thymic determinant of the balance between interferon-gamma-and interleukin 17-producing gamma delta T cell subsets. Nature Immunology 2009, 10:427-436.

2. Taghon T, Yui MA, Pant R, Diamond RA, Rothenberg EV: Developmental and molecular characterization of emerging beta- and gamma delta-selected pre-T cells in the adult mouse thymus. Immunity 2006, 24:53-64.

The authors show that the phenotypic, functional, and homeostatic characteristics of the $\mathrm{CD} 27^{+} \gamma \delta \mathrm{T}$ cell compartment is comparable to that of naive and memory $\mathrm{CD}^{+} \alpha \beta \mathrm{T}$ cells, unlike the $\mathrm{CD} 27^{-} \gamma \delta \mathrm{T}$ cell compartment in mice.

* 3. Lombes A, Durand A, Charvet C, Riviere M, Bonilla N, Auffray C, Lucas B, Martin B: Adaptive Immune-like gamma/delta $T$ Lymphocytes Share Many Common Features with Their alpha/beta $T$ Cell Counterparts. Journal of Immunology 2015, 195:1449-1458.

The authors show that the phenotypic, functional, and homeostatic characteristics of the $\mathrm{CD} 27^{+} \gamma \delta \mathrm{T}$ cell compartment is comparable to that of naive and memory $\mathrm{CD} 8^{+}$ $\alpha \beta$ T cells, unlike the $\mathrm{CD} 27^{-} \gamma \delta$ T cell compartment in mice.

4. Klein U, Rajewsky K, Kuppers R: Human immunoglobulin $(\mathbf{I g}) \mathbf{M}(+) \operatorname{IgD}(+)$ peripheral blood $B$ cells expressing the $C D 27$ cell surface antigen carry somatically mutated variable region genes: CD27 as a general marker for somatically mutated (memory) B cells. Journal of Experimental Medicine 1998, 188: 1679-1689.

5. Tangye SG, Liu YJ, Aversa G, Phillips JH, de Vries JE: Identification of functional human splenic memory $B$ cells by expression of CD148 and CD27. Journal of Experimental Medicine 1998, 188:1691-1703.

6. Fecteau JF, Cote G, Neron S: A new memory CD27(-)IgG(+) B cell population in peripheral blood expressing $\mathrm{V}-\mathrm{H}$ genes with low frequency of somatic mutation. Journal of Immunology 2006, 177:3728-3736.

7. Hayakawa Y, Smyth MJ: CD27 dissects mature NK cells into two subsets with distinct responsiveness and migratory capacity. Journal of Immunology 2006, 176:1517-1524.

8. Vossen MTM, Matmati M, Hertoghs KML, Baars PA, Gent NR, Leclercq G, Hamann J, Kuijpers TW, van Lier RAW: CD27 defines phenotypically and functionally different human NK cell subsets. Journal of Immunology 2008, 180:3739-3745.

9. Croft M: The role of TNF superfamily members in T-cell function and diseases. Nat Rev Immunol 2009, 9:271-285. 
10. Nolte MA, van Olffen RW, van Gisbergen KP, van Lier RA: Timing and tuning of CD27-CD70 interactions: the impact of signal strength in setting the balance between adaptive responses and immunopathology. Immunol Rev 2009, 229:216-231.

11. Rowley TF, Al-Shamkhani A: Stimulation by soluble CD70 promotes strong primary and secondary $\mathrm{CD8}+$ cytotoxic $\mathrm{T}$ cell responses in vivo. $J$ Immunol 2004, 172:6039-6046.

12. Hendricks J, Xiao YL, Borst J: CD27 promotes survival of activated T cells and complements $\mathrm{CD28}$ in generation and establishment of the effector $\mathrm{T}$ cell pool. Journal of Experimental Medicine 2003, 198:1369-1380.

13. Dolfi DV, Katsikis PD: CD28 and CD27 costimulation of CD8+ T cells: a story of survival. Adv Exp Med Biol 2007, 590:149-170.

14. Banchereau J, Steinman RM: Dendritic cells and the control of immunity. Nature 1998, 392:245-252.

15. Bennett SRM, Carbone FR, Karamalis F, Miller JFAP, Heath WR: Induction of a CD8(+) cytotoxic $T$ lymphocyte response by cross-priming requires cognate CD4(+) T cell help. Journal of Experimental Medicine 1997, 186:6570.

16. Ridge JP, Di Rosa F, Matzinger P: A conditioned dendritic cell can be a temporal bridge between a CD4+ T-helper and a T-killer cell. Nature 1998, 393:474-478.

17. Bedoui S, Heath WR, Mueller SN: CD4(+) T-cell help amplifies innate signals for primary CD8(+) T-cell immunity. Immunological Reviews 2016, 272:5264.

18. Mescher MF, Curtsinger JM, Agarwal P, Casey KA, Gerner M, Hammerbeck CD, Popescu F, Xiao Z: Signals required for programming effector and memory development by CD8+ T cells. Immunol Rev 2006, 211:81-92.

19. den Haan JM, Arens R, van Zelm MC: The activation of the adaptive immune system: cross-talk between antigen-presenting cells, $T$ cells and $B$ cells. Immunol Lett 2014, 162:103-112.

20. Hennecke J, Wiley DC: T cell receptor-MHC interactions up close. Cell 2001, 104:1-4.

21. Watts $\mathrm{TH}$ : $\mathbf{T n f} / \mathrm{tnfr}$ family members in costimulation of $\mathbf{T}$ cell responses. Annual Review of Immunology 2005, 23:23-68.

22. Esensten JH, Helou YA, Chopra G, Weiss A, Bluestone JA: CD28 Costimulation: From Mechanism to Therapy. Immunity 2016, 44:973-988.

23. June $\mathrm{CH}$, Bluestone JA, Nadler LM, Thompson CB: The $\mathbf{B} 7$ and $\mathrm{CD} 28$ receptor families. Immunol Today 1994, 15:321-331.

24. Curtsinger JM, Schmidt CS, Mondino A, Lins DC, Kedl RM, Jenkins MK, Mescher MF: Inflammatory cytokines provide a third signal for activation of naive CD4+ and CD8+ T cells. J Immunol 1999, 162:3256-3262.

25. Smith-Garvin JE, Koretzky GA, Jordan MS: T Cell Activation. Annual Review of Immunology 2009, 27:591-619.

26. Butcher EC, Picker LJ: Lymphocyte homing and homeostasis. Science 1996, 272:60-66.

27. van Lier RA, Borst J, Vroom TM, Klein H, Van Mourik P, Zeijlemaker WP, Melief CJ: Tissue distribution and biochemical and functional properties of Tp55 (CD27), a novel T cell differentiation antigen. J Immunol 1987, 139:1589-1596. 
28. Gravestein LA, Nieland JD, Kruisbeek AM, Borst J: Novel mAbs reveal potent co-stimulatory activity of murine CD27. Int Immunol 1995, 7:551-557.

29. Kobata T, Jacquot S, Kozlowski S, Agematsu K, Schlossman SF, Morimoto C: CD27-CD70 interactions regulate B-cell activation by $\mathbf{T}$ cells. Proc Natl Acad Sci U S A 1995, 92:11249-11253.

30. Denoeud J, Moser M: Role of CD27/CD70 pathway of activation in immunity and tolerance. J Leukoc Biol 2011, 89:195-203.

31. Wajant H: Therapeutic targeting of CD70 and CD27. Expert Opinion on Therapeutic Targets 2016, 20:959-973.

32. Sanchez PJ, McWilliams JA, Haluszczak C, Yagita H, Kedl RM: Combined TLR/CD40 stimulation mediates potent cellular immunity by regulating dendritic cell expression of CD70 in vivo. J Immunol 2007, 178:1564-1572.

33. Akiba H, Nakano H, Nishinaka S, Shindo M, Kobata T, Atsuta M, Morimoto C, Ware CF, Malinin NL, Wallach D, et al.: CD27, a member of the tumor necrosis factor receptor superfamily, activates NF-kappaB and stressactivated protein kinase/c-Jun N-terminal kinase via TRAF2, TRAF5, and NF-kappaB-inducing kinase. J Biol Chem 1998, 273:13353-13358.

34. van Oosterwijk MF, Juwana H, Arens R, Tesselaar K, van Oers MH, Eldering E, van Lier RA: CD27-CD70 interactions sensitise naive CD4+ $\mathbf{T}$ cells for IL12-induced Th1 cell development. Int Immunol 2007, 19:713-718.

35. Hintzen RQ, de Jong R, Lens SM, Brouwer M, Baars P, van Lier RA: Regulation of CD27 expression on subsets of mature T-lymphocytes. J Immunol 1993, 151:2426-2435.

36. Gravestein LA, van Ewijk W, Ossendorp F, Borst J: CD27 cooperates with the pre- $\mathrm{T}$ cell receptor in the regulation of murine $\mathrm{T}$ cell development. $J \operatorname{Exp}$ Med 1996, 184:675-685.

*37. Willoughby JE, Kerr JP, Rogel A, Taraban VY, Buchan SL, Johnson PW, AlShamkhani A: Differential impact of CD27 and 4-1BB costimulation on effector and memory CD8 $T$ cell generation following peptide immunization. J Immunol 2014, 193:244-251.

CD27 co-stimulation via the addition of sCD70 enhances primary and memory CD8 ${ }^{+}$ $\mathrm{T}$-cell responses and promotes retention of IL-7R $\alpha$.

38. Hendriks J, Gravestein LA, Tesselaar K, van Lier RA, Schumacher TN, Borst J: $\mathrm{CD} 27$ is required for generation and long-term maintenance of $\mathrm{T}$ cell immunity. Nat Immunol 2000, 1:433-440.

*39. Munitic I, Kuka M, Allam A, Scoville JP, Ashwell JD: CD70 deficiency impairs effector CD8 $T$ cell generation and viral clearance but is dispensable for the recall response to lymphocytic choriomeningitis virus. J Immunol 2013, 190:1169-1179.

Loss of CD27 co-stimulation in $\mathrm{CD} 70^{-/-}$mice decreases $\mathrm{CD}^{+} \mathrm{T}$ cell proliferation, differentiation and function, and reduces viral clearance during CMV infection.

40. Penaloza-MacMaster P, Ur Rasheed A, Iyer SS, Yagita H, Blazar BR, Ahmed R: Opposing effects of CD70 costimulation during acute and chronic lymphocytic choriomeningitis virus infection of mice. J Virol 2011, 85:6168-6174.

41. van Gisbergen KP, van Olffen RW, van Beek J, van der Sluijs KF, Arens R, Nolte MA, van Lier RA: Protective CD8 $\mathbf{T}$ cell memory is impaired during chronic CD70-driven costimulation. J Immunol 2009, 182:5352-5362. 
42. Dong H, Franklin NA, Roberts DJ, Yagita H, Glennie MJ, Bullock TN: CD27 stimulation promotes the frequency of IL-7 receptor-expressing memory precursors and prevents IL-12-mediated loss of CD8(+) T cell memory in the absence of CD4(+) T cell help. $J$ Immunol 2012, 188:3829-3838.

43. Gao J, Zhao L, Wan YY, Zhu B: Mechanism of Action of IL-7 and Its Potential Applications and Limitations in Cancer Immunotherapy. Int $\mathrm{J}$ Mol Sci 2015, 16:10267-10280.

44. Kaech SM, Tan JT, Wherry EJ, Konieczny BT, Surh CD, Ahmed R: Selective expression of the interleukin 7 receptor identifies effector $\mathrm{CD8} T$ cells that give rise to long-lived memory cells. Nat Immunol 2003, 4:1191-1198.

*45. Taraban VY, Rowley TF, Kerr JP, Willoughby JE, Johnson PM, Al-Shamkhani A, Buchan SL: CD27 costimulation contributes substantially to the expansion of functional memory $\mathbf{C D 8}(+) \quad T$ cells after peptide immunization. Eur J Immunol 2013, 43:3314-3323.

Enhancing CD27 co-stimulation with a CD27 agonistic mAb during secondary activation enhances recall.

46. Vitale LA, He LZ, Thomas LJ, Widger J, Weidlick J, Crocker A, O'Neill T, Storey J, Glennie MJ, Grote DM, et al.: Development of a human monoclonal antibody for potential therapy of CD27-expressing lymphoma and leukemia. Clin Cancer Res 2012, 18:3812-3821.

**47. Ramakrishna V, Sundarapandiyan K, Zhao B, Bylesjo M, Marsh HC, Keler T: Characterization of the human $T$ cell response to in vitro CD27 costimulation with varlilumab. J Immunother Cancer 2015, 3:37.

Increased CD27 co-stimulation with a novel anti-CD27 antibody named Varlilumab enhances cytokine production and can influence gene expression following polyclonal activation of human $\mathrm{T}$ cells by $\mathrm{CD} 3$ cross-linking.

48. Braun-Falco M, Hallek M: Recombinant adeno-associated virus (rAAV) vector-mediated cotransduction of CD70 and CD80 into human malignant melanoma cells results in an additive $\mathbf{T}$-cell response. Arch Dermatol Res 2001, 293:12-17.

49. Salzer E, Daschkey S, Choo S, Gombert M, Santos-Valente E, Ginzel S, Schwendinger M, Haas OA, Fritsch G, Pickl WF, et al.: Combined immunodeficiency with life-threatening EBV-associated lymphoproliferative disorder in patients lacking functional CD27. Haematologica 2013, 98:473-478.

50. van Montfrans JM, Hoepelman AI, Otto S, van Gijn M, van de Corput L, de Weger RA, Monaco-Shawver L, Banerjee PP, Sanders EA, Jol-van der Zijde $\mathrm{CM}$, et al.: CD27 deficiency is associated with combined immunodeficiency and persistent symptomatic EBV viremia. J Allergy Clin Immunol 2012, 129:787-793 e786.

51. Ribot JC, Chaves-Ferreira M, d'Orey F, Wencker M, Goncalves-Sousa N, Decalf J, Simas JP, Hayday AC, Silva-Santos B: Cutting Edge: Adaptive Versus Innate Receptor Signals Selectively Control the Pool Sizes of Murine IFNgamma- or IL-17-Producing gamma delta T Cells upon Infection. Journal of Immunology 2010, 185:6421-6425.

52. DeBarros A, Chaves-Ferreira M, d'Orey F, Ribot JC, Silva-Santos B: CD70CD27 interactions provide survival and proliferative signals that regulate 
T cell receptor-driven activation of human gammadelta peripheral blood lymphocytes. Eur J Immunol 2011, 41:195-201.

53. Kruetzmann S, Rosado MM, Weber H, Germing U, Tournilhac O, Peter HH, Berner R, Peters A, Boehm T, Plebani A, et al.: Human immunoglobulin M memory $B$ cells controlling Streptococcus pneumoniae infections are generated in the spleen. Journal of Experimental Medicine 2003, 197:939945.

54. Han BK, White AM, Dao KH, Karp DR, Wakeland EK, Davis LS: Increased prevalence of activated $\mathrm{CD70}+\mathrm{CD} 4+\mathrm{T}$ cells in the periphery of patients with systemic lupus erythematosus. Lupus 2005, 14:598-606.

55. Lee WW, Yang ZZ, Li G, Weyand CM, Goronzy JJ: Unchecked CD70 expression on $\mathbf{T}$ cells lowers threshold for $\mathbf{T}$ cell activation in rheumatoid arthritis. J Immunol 2007, 179:2609-2615.

56. Nakajima A, Oshima H, Nohara C, Morimoto S, Yoshino S, Kobata T, Yagita H, Okumura K: Involvement of CD70-CD27 interactions in the induction of experimental autoimmune encephalomyelitis. J Neuroimmunol 2000, 109:188-196.

57. Oflazoglu E, Boursalian TE, Zeng W, Edwards AC, Duniho S, McEarchern JA, Law CL, Gerber HP, Grewal IS: Blocking of CD27-CD70 pathway by antiCD70 antibody ameliorates joint disease in murine collagen-induced arthritis. J Immunol 2009, 183:3770-3777.

58. Manocha M, Rietdijk S, Laouar A, Liao G, Bhan A, Borst J, Terhorst C, Manjunath N: Blocking CD27-CD70 costimulatory pathway suppresses experimental colitis. J Immunol 2009, 183:270-276.

59. Kahan SM, Wherry EJ, Zajac AJ: T cell exhaustion during persistent viral infections. Virology 2015.

60. De Milito A, Nilsson A, Titanji K, Thorstensson R, Reizenstein E, Narita M, Grutzmeier S, Sonnerborg A, Chiodi F: Mechanisms of hypergammaglobulinemia and impaired antigen-specific humoral immunity in HIV-1 infection. Blood 2004, 103:2180-2186.

61. Wolthers KC, Otto SA, Lens SM, Kolbach DN, van Lier RA, Miedema F, Meyaard L: Increased expression of CD80, CD86 and CD70 on T cells from HIV-infected individuals upon activation in vitro: regulation by CD4+ T cells. Eur J Immunol 1996, 26:1700-1706.

62. Matter M, Odermatt B, Yagita H, Nuoffer JM, Ochsenbein AF: Elimination of chronic viral infection by blocking CD27 signaling. J Exp Med 2006, 203:2145-2155.

63. Held-Feindt J, Mentlein R: CD70/CD27 ligand, a member of the TNF family, is expressed in human brain tumors. Int J Cancer 2002, 98:352-356.

64. Diegmann J, Junker K, Gerstmayer B, Bosio A, Hindermann W, Rosenhahn J, von Eggeling F: Identification of $\mathrm{CD70}$ as a diagnostic biomarker for clear cell renal cell carcinoma by gene expression profiling, real-time RT-PCR and immunohistochemistry. Eur J Cancer 2005, 41:1794-1801.

65. Grewal IS: CD70 as a therapeutic target in human malignancies. Expert Opin Ther Targets 2008, 12:341-351.

66. Jacobs J, Deschoolmeester V, Zwaenepoel K, Rolfo C, Silence K, Rottey S, Lardon F, Smits E, Pauwels P: CD70: An emerging target in cancer immunotherapy. Pharmacol Ther 2015. 
67. Schaer DA, Hirschhorn-Cymerman D, Wolchok JD: Targeting tumor-necrosis factor receptor pathways for tumor immunotherapy. $J$ Immunother Cancer 2014, 2:7.

68. Sanmamed MF, Pastor F, Rodriguez A, Perez-Gracia JL, Rodriguez-Ruiz ME, Jure-Kunkel M, Melero I: Agonists of Co-stimulation in Cancer Immunotherapy Directed Against CD137, OX40, GITR, CD27, CD28, and ICOS. Semin Oncol 2015, 42:640-655.

69. Cormary C, Gonzalez R, Faye JC, Favre G, Tilkin-Mariame AF: Induction of Tcell antitumor immunity and protection against tumor growth by secretion of soluble human CD70 molecules. Cancer Gene Ther 2004, 11:497-507.

70. Lorenz MG, Kantor JA, Schlom J, Hodge JW: Anti-tumor immunity elicited by a recombinant vaccinia virus expressing CD70 (CD27L). Hum Gene Ther 1999, 10:1095-1103.

71. 2014. CT-hiccrcRrpo: Celldex Therapeutics' Varlilumab Continues to Demonstrate Very Favorable Profile. In ASCO Annual Meeting 2014. Edited by. Chicago, IL, USA; 2014.

**72. Buchan SL, Manzo T, Flutter B, Rogel A, Edwards N, Zhang L, Sivakumaran S, Ghorashian S, Carpenter B, Bennett CL, et al.: OX40- and CD27mediated costimulation synergizes with anti-PD-L1 blockade by forcing exhausted CD8+ T cells to exit quiescence. J Immunol 2015, 194:125-133.

Augmenting CD27 co-stimulation with an agonistic CD27 mAb in the absence of inflammation can rescue exhausted cells. 


\section{Highlights}

- CD27 is a co-stimulatory receptor expressed on T-cells, B-cells and NK-cells

- CD27-CD70 co-stimulation enhances primary, memory and recall T-cell responses

- Manipulating CD27-CD70 signalling is of interest for a variety of immunotherapies 


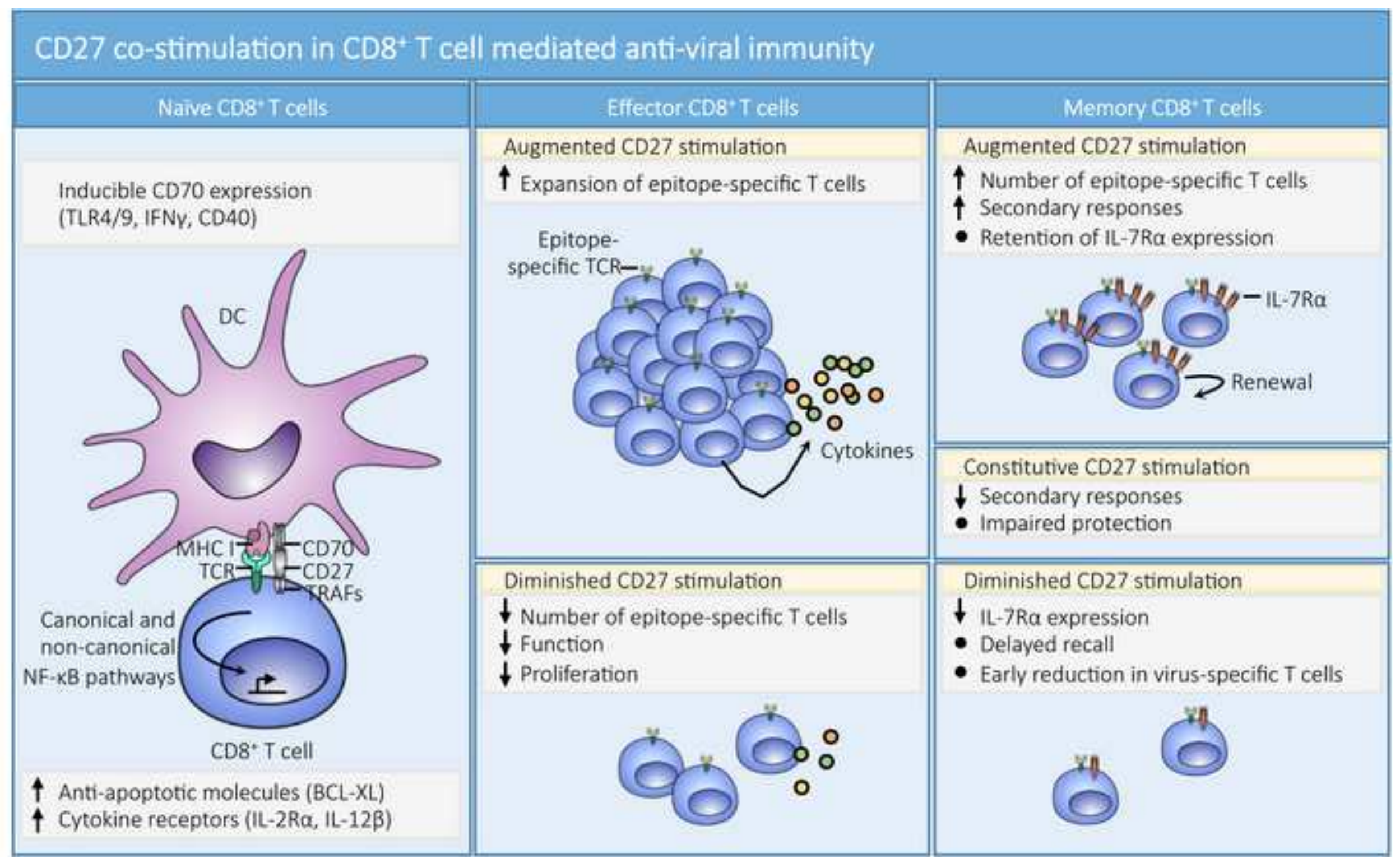


Table 1. Publications describing the role of CD27 co-stimulation in mice

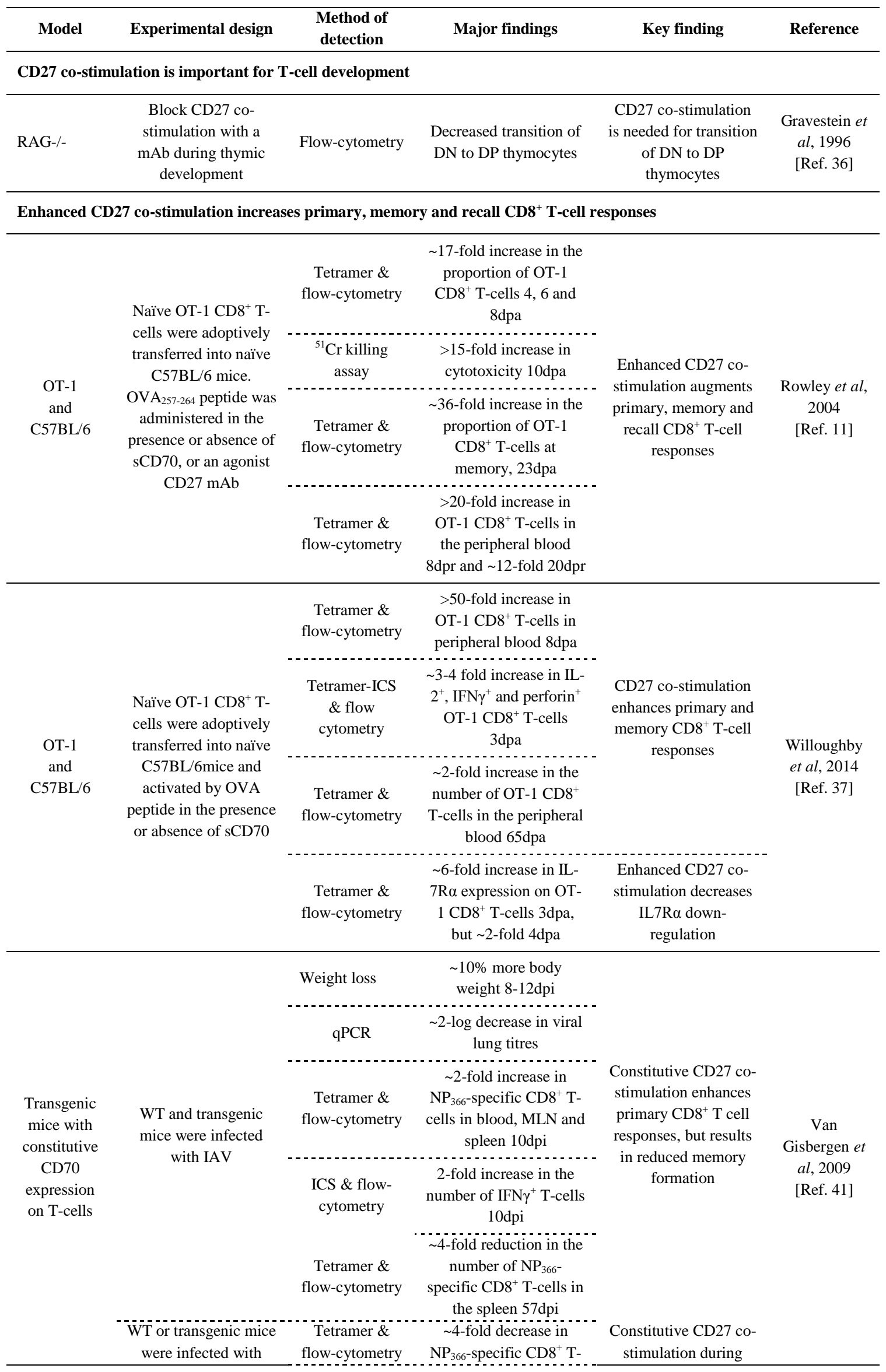




\begin{tabular}{|c|c|c|c|c|c|}
\hline & $\begin{array}{c}\text { IAV then challenged } \\
51-61 \text { days later with a } \\
\text { serologically distinct } \\
\text { IAV }\end{array}$ & $\begin{array}{l}\text { ICS and flow- } \\
\text { cytometry }\end{array}$ & $\begin{array}{l}\text { cells in the spleen and } \\
\text { blood } 8 \mathrm{dpc} \\
\text { 4-fold decrease in the } \\
\text { number of IFN } \gamma^{+} \mathrm{CD}^{+} \\
\text {T-cells } 8 \mathrm{dpc}\end{array}$ & $\begin{array}{c}\text { both primary and } \\
\text { secondary activation } \\
\text { decreases recall }\end{array}$ & \\
\hline $\mathrm{CD} 27^{-/-}$ & $\begin{array}{l}\mathrm{CD} 27^{-/-} \text {and WT mice } \\
\text { were infected with } \\
\text { IAV } \\
\text { CD27/- or WT mice } \\
\text { were infected with } \\
\text { IAV and challenged } 6 \\
\text { weeks later }\end{array}$ & $\begin{array}{c}\text { Tetramer \& } \\
\text { flow-cytometry }\end{array}$ & 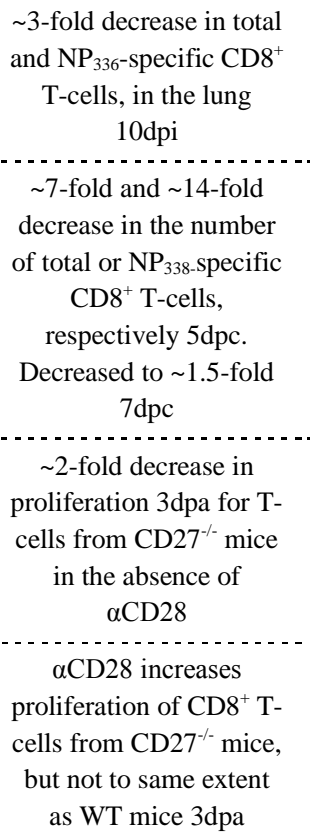 & $\begin{array}{l}\text { Loss of CD27 co- } \\
\text { stimulation decreases } \\
\text { CD8 }{ }^{+} \text {T-cell } \\
\text { proliferation } \\
\text { Loss of CD27 co- } \\
\text { stimulation delays } \\
\text { recall during } \\
\text { secondary IAV } \\
\text { infection }\end{array}$ & $\begin{array}{c}\text { Hendricks et } \\
\text { al, 2003 } \\
\text { [Ref. 12] }\end{array}$ \\
\hline $\begin{array}{l}\mathrm{CD}^{2} 0^{-/-} \text {and } \\
\mathrm{C} 57 \mathrm{BL} / 6\end{array}$ & $\begin{array}{c}\mathrm{CD}^{-/-} \text {or WT mice } \\
\text { were infected with } \\
\text { acute LCMV }\end{array}$ & $\begin{array}{l}\text { Tetramers } \\
\text { Flow cytometry } \\
\text { ICS \& flow- } \\
\text { cytometry } \\
\text { qRT-PCR }\end{array}$ & $\begin{array}{c}<2 \text {-fold decrease in total } \\
\text { and } \mathrm{NP}_{396} \text {-specific } \mathrm{CD}^{+} \\
\text {T-cells, 6-8dpi } \\
\text { Decreased } \\
\text { differentiation by } \\
\text { CD44 }{ }^{\text {hi }} \text { and CD62L } \\
\text { expression 8dpi } \\
\text { 2-fold reduction in } \\
\text { IFN } \gamma \text {, TNF and IL-2 6- } \\
\text { 8dpi } \\
\text { viral clearance } 6 \text { and } \\
\text { 8dpi }\end{array}$ & $\begin{array}{l}\text { Loss of CD27 co- } \\
\text { stimulation decreases } \\
\text { epitope-specific } \\
\text { proliferation, } \\
\text { differentiation and } \\
\text { function, and reduces } \\
\text { viral clearance }\end{array}$ & $\begin{array}{c}\text { Munitic et al, } \\
2013 \\
\text { [Ref. 39] }\end{array}$ \\
\hline C57BL/6 & $\begin{array}{l}\text { C57BL/6 mice were } \\
\text { infected with acute } \\
\text { LCMV in the absence } \\
\text { or presence of a CD70 } \\
\text { blocking mAb }\end{array}$ & $\begin{array}{l}\text { ICS \& flow- } \\
\text { cytometry }\end{array}$ & $\begin{array}{c}\sim 6 \text {-fold reduction in the } \\
\text { proportion and numbers } \\
\text { of IFN } \gamma^{+} \mathrm{TNF}^{+} \text {cells } \\
7 \mathrm{dpi} .\end{array}$ & $\begin{array}{l}\text { Loss of CD27 co- } \\
\text { stimulation decreases } \\
\text { the function of } \\
\text { epitope-specific } \mathrm{CD}^{+} \\
\text {T-cells }\end{array}$ & $\begin{array}{l}\text { Penaloza- } \\
\text { McMaster et } \\
\text { al, 2011 } \\
\text { [Ref. 40] }\end{array}$ \\
\hline $\begin{array}{c}\text { OT-1 } \\
\text { And } \\
\text { C57BL/6 }\end{array}$ & $\begin{array}{c}\text { OT-1 CD8 }{ }^{+} \text {T-cells } \\
\text { were transferred into } \\
\text { C57BL/6 mice. Mice } \\
\text { were vaccinated with } \\
\text { OVA-vac and treated } \\
\text { with or without an } \\
\alpha C D 70 \text { - blocking mAb }\end{array}$ & $\begin{array}{c}\text { Tetramer \& } \\
\text { flow-cytometry }\end{array}$ & $\begin{array}{l}\text { 5-fold decrease in the } \\
\text { number of resting } \\
\text { memory OT-1 CD8 }{ }^{+} \mathrm{T} \text { - } \\
\text { cells 90dpa } \\
\text { 2-fold decrease in } \\
\text { IL7R } \alpha \text { expression } 7 \mathrm{dpa}\end{array}$ & $\begin{array}{l}\text { Blocking CD27 co- } \\
\text { stimulation decreases } \\
\text { the number of IL-7R } \alpha \\
\text { expressing memory } \\
\text { precursor cells }\end{array}$ & $\begin{array}{l}\text { Dong et al, } \\
2012 \\
\text { [Ref. 42] }\end{array}$ \\
\hline C57BL/6 & $\begin{array}{l}\text { C57BL/6 mice were } \\
\text { immunised with OVA } \\
\text { peptide and an } \\
\text { agonistic anti-CD40 } \\
\text { antibody and recalled } \\
\text { 15-48 days later with } \\
\text { OVA peptide, in the } \\
\text { absence or presence of } \\
\text { a CD27 agonist mAb }\end{array}$ & $\begin{array}{c}\text { Tetramer \& } \\
\text { flow-cytometry }\end{array}$ & $\begin{array}{l}\text { 8-fold increase in total } \\
\text { OVA }_{257-264^{-}} \text {specific } \\
\mathrm{CD}^{+} \text {T-cells } 8 \mathrm{dpr}\end{array}$ & $\begin{array}{l}\text { Enhanced CD27 co- } \\
\text { stimulation during } \\
\text { secondary activation } \\
\text { enhances recall }\end{array}$ & $\begin{array}{c}\text { Taraban et } \\
\text { al, 2013 } \\
\text { [Ref. 45] }\end{array}$ \\
\hline
\end{tabular}


$\mathrm{IAV}=$ influenza $\mathrm{A}$ virus, $\mathrm{dpi}=$ days post infection, $\mathrm{dpa}=$ days post activation, $\mathrm{dpt}=$ days post transfer, pdc=days post challenge, $\mathrm{dpr}=\mathrm{days}$ post recall 
Table 2. Summary of publications describing the role of CD27 co-stimulation on human T-cells

\begin{tabular}{|c|c|c|c|c|c|}
\hline Model & Experimental design & Method of detection & Major findings & Key finding & Reference \\
\hline \multicolumn{6}{|c|}{ CD27 co-stimulation enhances T-cell function in humans } \\
\hline $\begin{array}{l}\text { Human T- } \\
\text { cells }\end{array}$ & $\begin{array}{c}\text { PBMCs were negatively } \\
\text { enriched for T-cells. } \\
\text { Stimulated with a suboptimal } \\
\text { dose of ConA in the presence } \\
\text { Colo679-CD70 }{ }^{+} \text {or Colo679- } \\
\text { CD70 cells }\end{array}$ & Thymidine incorporation & $\begin{array}{l}\sim 2 \text {-fold decrease in } \\
\text { proliferation }\end{array}$ & $\begin{array}{l}\text { CD27 co- } \\
\text { stimulation } \\
\text { increases } \\
\text { proliferation }\end{array}$ & $\begin{array}{c}\text { Braun-Falco } \\
\text { et al, } 2001 \\
\text { [Ref. 48] }\end{array}$ \\
\hline $\begin{array}{l}\text { Human T- } \\
\text { cells }\end{array}$ & $\begin{array}{c}\mathrm{CD}^{+} \mathrm{T} \text {-cells were activated } \\
\text { by } \alpha \mathrm{CD} 3 \text { cross-linking with } \\
\text { or without cross-linking } \\
\mathrm{CD} 27 \text { with plate bound } \\
\text { Varlilumab }\end{array}$ & $\begin{array}{c}\text { cellTitre-Glo } \\
\text { luminescence assay }\end{array}$ & $\begin{array}{l}\text { 4-fold increase in } \\
\text { proliferation 5pda } \\
\text { and TNF production } \\
\text { 2dpa }\end{array}$ & $\begin{array}{l}\text { Enhanced } \\
\text { CD27 co- } \\
\text { stimulation } \\
\text { increases } \\
\text { proliferation } \\
\text { and function } \\
\end{array}$ & $\begin{array}{c}\text { Vitale et al, } \\
2012 \\
\text { [Ref. 46] }\end{array}$ \\
\hline $\begin{array}{l}\text { Human T- } \\
\text { cells }\end{array}$ & $\begin{array}{c}\mathrm{CD}^{+} \mathrm{T} \text {-cells were activated } \\
\text { by } \alpha \mathrm{CD} 3 \text { cross-linking with } \\
\text { or without CD27 cross- } \\
\text { linking with plate bound } \\
\text { Varlilumab } \\
\text { CD3 }{ }^{+} \text {T-cells cultures were } \\
\text { activated with } \alpha \mathrm{CD} 3 \text { cross- } \\
\text { lining with irradiated CD70- } \\
\text { expressing cells } \\
\text { CD3 }{ }^{+} \text {T-cells were activated } \\
\text { by } \alpha \mathrm{CD} 3 \text { cross-linking with } \\
\text { or without cross-linking } \\
\mathrm{CD} 27 \text { with plate bound } \\
\text { Varlilumab }\end{array}$ & Gene microarray & $\begin{array}{l}\sim 4 \text {-fold increase in } \\
\text { IFN } \gamma \text {, TNF, IL-2 and IL- } \\
13 \text { production } 72 \mathrm{hpa} \\
\text { and IL-13 production } \\
72 \mathrm{hpa} \\
\text { CD27 co-stimulation } \\
\text { resulted in a distinct } \\
\text { gene expression profile }\end{array}$ & $\begin{array}{l}\text { Increased } \\
\text { CD27 co- } \\
\text { stimulation } \\
\text { enhances } \\
\text { cytokine } \\
\text { production }\end{array}$ & $\begin{array}{c}\text { Ramakrishna } \\
\text { et al, 2015 } \\
\text { [Ref. 47] }\end{array}$ \\
\hline
\end{tabular}

dpa $=$ days post activation, hpa=hours post activation 
Table 3. Publications investigating the influence of CD27 co-stimulation on $\gamma \delta$ T-cells

\begin{tabular}{|c|c|c|c|c|c|}
\hline Model & Experimental design & $\begin{array}{l}\text { Method of } \\
\text { detection }\end{array}$ & Major findings & Key finding & Reference \\
\hline \multicolumn{6}{|c|}{ Mouse studies } \\
\hline $\mathrm{C57BL/6}$ & $\begin{array}{l}\text { Total } \gamma \delta \text { T-cells from spleen } \\
\text { and LN were stimulated with } \\
\alpha C D 3 \text { supplemented with } \\
\text { sCD70 }\end{array}$ & $\begin{array}{l}\text { CBA and flow } \\
\text { cytometery }\end{array}$ & $\begin{array}{l}\text { Dose dependent increase in } \\
\text { survival and expression of pro- } \\
\text { inflammatory cytokines }\end{array}$ & $\begin{array}{c}\text { CD27 co-stimulation supported } \\
\text { survival and proliferation of } \gamma \delta \\
\text { T cells }\end{array}$ & \multirow{2}{*}{$\begin{array}{c}\text { Ribot et al, } \\
2010 \\
\text { [Ref. 51] }\end{array}$} \\
\hline $\begin{array}{l}\text { WT and } \\
\text { CD27 } 7^{-/}\end{array}$ & $\begin{array}{c}\text { Mice were infected with } \\
\text { murine herpes virus and } \\
\text { malaria }\end{array}$ & ICS & $\begin{array}{c}\sim 1 \text { to } 4 \text { fold increase in } \\
\text { proportion IFN } \gamma \text { producing } \gamma \delta \\
\text { T-cells }\end{array}$ & $\begin{array}{l}\text { Loss of CD27 co-stimulation } \\
\text { decreased IFN } \gamma \text { production }\end{array}$ & \\
\hline C57BL/6 & $\begin{array}{l}\text { Thymic and splenic } \gamma \delta \mathrm{T}- \\
\text { cells were isolated from } \\
\text { embryonic, newborn and } \\
\text { adult C57BL/6 mice }\end{array}$ & Flow cytometery & $\begin{array}{l}90 \% \text { of } \gamma \delta \text { thymocytes were } \\
\qquad \mathrm{CD} 27^{\text {hi }}\end{array}$ & $\begin{array}{l}\text { CD27 expression defines stable } \\
\text { IFN } \gamma \text {-producing and IL-17- } \\
\text { producing } \gamma \delta \text { subsets }\end{array}$ & \multirow{3}{*}{$\begin{array}{c}\text { Ribot et al, } \\
2009 \\
\text { [Ref. 1] }\end{array}$} \\
\hline $\begin{array}{l}\text { WT, TCR } \alpha- \\
\text { and TCR } \beta- \\
\text { deficient, } \\
\text { CD27 } \\
-\end{array}$ & $\begin{array}{l}\text { Peripheral } \gamma \delta \text { T-cells were } \\
\text { isolated }\end{array}$ & $\begin{array}{l}\text { Real time PCR } \\
\text { and flow } \\
\text { cytometery }\end{array}$ & $\begin{array}{l}\text { Decrease in IFN } \gamma \text { expression } \\
\text { levels in peripheral }\end{array}$ & $\begin{array}{l}\text { Loss of CD27 co-stimulation } \\
\text { decreases IFN } \gamma \text { expression }\end{array}$ & \\
\hline $\begin{array}{c}\text { FTOC } \gamma \delta \\
\text { thymocytes }\end{array}$ & $\begin{array}{l}\text { FTOC } \gamma \delta \text { thymocytes were } \\
\text { treated with sCD70 and } \\
\text { immunoglobulin }\end{array}$ & Real time PCR & $\begin{array}{l}\text { Upregulation of IFN } \gamma \text { in CD27- } \\
\text { expressing } \gamma \delta \text {-thymocytes and } \\
\text { down-regulation of IL- } 17 \text { in } \\
\text { CD27-negative } \gamma \delta \text {-thymocytes }\end{array}$ & $\begin{array}{c}\text { Enhanced CD27 co-stimulation } \\
\text { affected IFN- } \gamma \text { and IL-17 } \\
\text { expression }\end{array}$ & \\
\hline \multicolumn{6}{|c|}{ Human studies } \\
\hline $\begin{array}{c}\gamma 9 \delta 2 \text { T-cell } \\
\text { line }\end{array}$ & $\begin{array}{c}\gamma 9 \delta 2 \text { cells were enriched } \\
\text { from phosphoantigen } \\
\text { expanded PBMCs. MACS- } \\
\text { sorted } \gamma \delta \text { T-cells were } \\
\text { stimulated with } \\
\text { phosphoantigen in the } \\
\text { presence of sCD70 or } \\
\alpha C D 70\end{array}$ & CFSE and CBA & $\begin{array}{l}\text { Augmented proliferation and } \\
\text { increase in Th1 effector } \\
\text { functions }\end{array}$ & $\begin{array}{l}\text { Enhanced CD27 co-stimulation } \\
\text { increases proliferation, survival } \\
\text { and cytokine production }\end{array}$ & $\begin{array}{c}\text { DeBarros et } \\
a l, 2011 \\
\text { [Ref. 52] }\end{array}$ \\
\hline
\end{tabular}


Table 4. Publications blocking CD27 co-stimulation for immunotherapy in mice

\begin{tabular}{|c|c|c|c|c|c|}
\hline Model & Experimental design & Method of detection & Major findings & Key finding & Reference \\
\hline \multicolumn{6}{|c|}{ Blocking CD27 co-stimulation protects against autoimmunity } \\
\hline $\mathrm{SJL} / \mathrm{J}$ & $\begin{array}{l}\text { SJL/J mice were injected } \\
\text { with } \text { PLP }_{139} \text { to initiate } \\
\text { experimental autoimmune } \\
\text { encephalomyelitis (EAE) } \\
\text { in the presence or absence } \\
\text { of } \alpha \mathrm{CD} 70 \text { blocking mAb }\end{array}$ & Activity score & $\begin{array}{l}\sim 3 \text {-fold decrease in } \\
\text { mean clinical score } \\
\text { up to 50dpi }\end{array}$ & $\begin{array}{l}\text { Early blocking } \\
\text { CD27 co- } \\
\text { stimulation } \\
\text { reduces EAE a } \\
\text { murine model of } \\
\text { multiple sclerosis }\end{array}$ & $\begin{array}{c}\text { Nakajima } \\
\text { et al, 2000 } \\
\text { [Ref. 56] }\end{array}$ \\
\hline DBA/1 & $\begin{array}{l}\text { DBA/1 mice were injected } \\
\text { with Bovine CII in CFA } \\
\text { on day } 0 \text { and } 21 \text { to initiate } \\
\text { murine induced collagen } \\
\text { arthritis in the presence of } \\
\text { an } \alpha \text { CD70 blocking } \\
\text { antibody from day } 21\end{array}$ & $\begin{array}{c}\text { Clinical score } \\
\text { Histopathology vscore }\end{array}$ & $\begin{array}{c}\begin{array}{c}\sim \text {-fold reduction in } \\
\text { clinical score up to } \\
25 \text { days post } \\
\text { treatment }\end{array} \\
\begin{array}{c}\sim 1.5 \text {-fold reduction } \\
\text { in histopathology } \\
\text { score }\end{array}\end{array}$ & $\begin{array}{l}\text { Blocking CD27 } \\
\text { co-stimulation } \\
\text { reduces induced } \\
\text { collagen arthritis } \\
\text { in a murine } \\
\text { model }\end{array}$ & $\begin{array}{c}\text { Oflazoglu } \\
\text { et al, 2009 } \\
\text { [Ref. 57] }\end{array}$ \\
\hline $\begin{array}{l}\mathrm{C} 57 \mathrm{BL} / 6 \\
\text { and } \\
\mathrm{RAG}^{-/-}\end{array}$ & $\begin{array}{l}\mathrm{CD}^{+} \mathrm{CD}^{+} \mathrm{RB}^{\mathrm{hi}} \text { naïve T- } \\
\text { cells from C57BL/6 mice } \\
\text { were transferred into RAG } \\
{ }_{1-} \text { mice to initiate } \\
\text { experimental colitis with } \\
\text { or without } \alpha \mathrm{CD} 70 \\
\text { blocking mAb (pre- } \\
\text { symptomatic) } \\
\text { Experimental colitis was } \\
\text { established and mice were } \\
\text { treated with or without } \\
\alpha \mathrm{CD} 70 \text { blocking mAb } 5 \\
\text { weeks post transfer (post- } \\
\text { symptomatic) }\end{array}$ & Activity index & 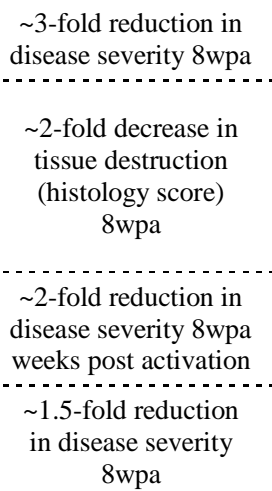 & $\begin{array}{c}\text { Blocking CD27 } \\
\text { co-stimulation } \\
\text { prevents } \\
\text { establishment and } \\
\text { reduces severity } \\
\text { of experimental } \\
\text { colitis in a murine } \\
\text { model of } \\
\text { inflammatory } \\
\text { bowel disease }\end{array}$ & $\begin{array}{c}\text { Manocha } \\
\text { et al, 2009 } \\
\text { [Ref. 58] }\end{array}$ \\
\hline
\end{tabular}

Blocking CD27 co-stimulation protects against chronic viral infection

\begin{tabular}{|c|c|c|c|c|c|}
\hline $\begin{array}{l}\text { Transgenic } \\
\text { mice with } \\
\text { constitutive } \\
\text { CD70 } \\
\text { expression } \\
\text { on T cells }\end{array}$ & $\begin{array}{l}\text { Naïve mice were assessed } \\
\text { at } 8 \text { weeks of age } \\
\text { TEM cells isolated at } 30 \\
\text { weeks of age stimulated } \\
\text { with PMA/Ionomycin }\end{array}$ & Flow-cytometry & $\begin{array}{l}\sim 5 \text {-fold increase in } \\
\text { CD8 } 8^{+} \text {TEM T-cells in } \\
\text { the spleen with a } \\
\text { more exhausted } \\
\text { phenotype including } \\
\text { increased CD69 and } \\
\text { PD-1 expression, and } \\
\text { decreased IL7R } \alpha \\
\text { expression } \\
\sim 2 \text {-fold decrease in } \\
\text { polyfunctionality } \\
\text { (IL2 } 2^{+} \text {TNF } \alpha^{+} \text {) of } \\
\text { CD8 } 8^{+} \mathrm{T}-\text { cells } \\
\text { following } \\
\text { restimulation }\end{array}$ & $\begin{array}{l}\text { Constitutive } \\
\text { CD27 co- } \\
\text { stimulation } \\
\text { deregulates } \\
\text { differentiation }\end{array}$ & $\begin{array}{l}\text { Van } \\
\text { Gisbergen } \\
\text { et al, 2009 } \\
\text { [Ref. 41] }\end{array}$ \\
\hline C57BL/6 & $\begin{array}{l}\text { Mice were infected with } \\
\text { chronic LCMV in the } \\
\text { presence or absence of an } \\
\alpha C D 70 \text { blocking mAb }\end{array}$ & ICS \& flow-cytometry & $\begin{array}{l}\sim 1.5 \text {-fold increase in } \\
\text { the number of IFN } \gamma \\
\text { expressing cells } \\
\text { following } \\
\text { restimulation with } \\
\text { peptide in an ICS } \\
\text { assay } 21 \mathrm{dpi} \text {. <1-fold } \\
\text { change } 7 \text { dpi. }\end{array}$ & $\begin{array}{l}\text { Blocking CD27 } \\
\text { co-stimulation } \\
\text { increases epitope- } \\
\text { specific CD8 }{ }^{+} \mathrm{T}- \\
\text { cell numbers }\end{array}$ & $\begin{array}{l}\text { Penaloza- } \\
\text { McMaster } \\
\text { et al, 2011 } \\
\text { [Ref. 40] }\end{array}$ \\
\hline C57BL/6 & $\begin{array}{l}\text { Mice were infected with a } \\
\text { chronic strain of LCMV in } \\
\text { the presence or absence of } \\
\text { an } \alpha \text { CD70 blocking mAb }\end{array}$ & $\begin{array}{l}\text { Immunological focus } \\
\text { assay }\end{array}$ & $\begin{array}{l}\sim 1.5-\log \text { decrease in } \\
\text { viral titres 66dpi }\end{array}$ & $\begin{array}{l}\text { Blocking CD27 } \\
\text { co-stimulation } \\
\text { increases viral } \\
\text { clearance }\end{array}$ & $\begin{array}{l}\text { Matter et } \\
\text { al, 2006 } \\
\text { [Ref. 62] }\end{array}$ \\
\hline
\end{tabular}


Table 5. Publications augmenting CD27 co-stimulation for immunotherapy

\begin{tabular}{|c|c|c|c|c|c|}
\hline Model & Experimental design & $\begin{array}{l}\text { Method of } \\
\text { detection }\end{array}$ & Major findings & Key finding & Reference \\
\hline \multicolumn{6}{|c|}{ Augmenting CD27 co-stimulation can rescue exhausted cells } \\
\hline C57BL/6 & $\begin{array}{l}\text { TCR-transgenic Mh } \mathrm{CD}^{+} \mathrm{T}- \\
\text { cells were adoptively transferred } \\
\text { into male MHC-matched bone } \\
\text { marrow transfer recipients in the } \\
\text { presence or absence of an } \\
\text { agonistic CD27 mAb } \\
\text { Additional blockade of PD-1 }\end{array}$ & $\begin{array}{l}\text { Thymidine } \\
\text { incorporation }\end{array}$ & $\begin{array}{l}\text { 2-fold increase in } \\
\text { Mh CD8 }{ }^{+} \mathrm{T} \text {-cell } \\
\text { proliferation }\end{array}$ & $\begin{array}{l}\text { Augmenting } \\
\text { CD27 co- } \\
\text { stimulation in the } \\
\text { absence of } \\
\text { inflammation can } \\
\text { rescue exhausted } \\
\text { cells }\end{array}$ & $\begin{array}{l}\text { Buchan et } \\
\text { al, 2015 } \\
\text { [Ref. 72] }\end{array}$ \\
\hline \multicolumn{6}{|c|}{ Augmented CD27 co-stimulation enhances anti-tumour immunity in mice } \\
\hline BalbC & $\begin{array}{l}\text { Mice were injected with live } \\
\text { tumour-inducing TSA-WT in } \\
\text { combination with irradiated } \\
\text { (non-tumour inducing) } \\
\text { transfected (mock or CD70- } \\
\text { secreting) TSA or MC57 cells }\end{array}$ & Observation & $\begin{array}{l}\sim 20 \% \text { increase in } \\
\text { non-tumour } \\
\text { development } 27 \mathrm{dpi} \\
\text { and } \sim 1.5 \text {-fold } \\
\text { reduction in tumour } \\
\text { size } 28 \mathrm{dpi}\end{array}$ & $\begin{array}{l}\text { Enhancing CD27 } \\
\text { co-stimulation } \\
\text { increases tumour } \\
\text { immunogenicity }\end{array}$ & $\begin{array}{c}\text { Cormary et } \\
\text { al, 2004 } \\
\text { [Ref. 69] }\end{array}$ \\
\hline $\mathrm{C} 57 \mathrm{BL} / 6$ & $\begin{array}{l}\text { Mice were injected with } \\
\text { tumour-inducing MC38 cells } \\
\text { that were uninfected or } \\
\text { infected with VV-WT or } \\
\text { VV-CD70+ } \\
\text { Mice were vaccinated with } \\
\text { HBSS or MC38 cells } \\
\text { infected with VV-CD70 } \\
\text { Mice were challenged with } \\
\text { uninfected MC38 cells on the } \\
\text { opposite flank }\end{array}$ & Observation & $\begin{array}{l}\text { Complete protection } \\
\text { against tumour } \\
\text { development 28dpt }\end{array}$ & $\begin{array}{l}\text { Augmented } \\
\text { CD27 co- } \\
\text { stimulation } \\
\text { prevents tumour } \\
\text { formation }\end{array}$ & $\begin{array}{l}\text { Lorenz et } \\
\text { al, } 1999 \\
{[\text { Ref. 70] }}\end{array}$ \\
\hline
\end{tabular}

Augmented CD27 co-stimulation increases anti-tumour immunity in humans

\begin{tabular}{|c|c|c|c|c|c|}
\hline $\begin{array}{l}\text { Humans in a } \\
\text { clinical trial } \\
\text { treated with } \\
\text { Varlilumab, } \\
\text { an } \alpha C D 27 \\
\text { agonist mAb }\end{array}$ & $\begin{array}{l}\text { Humans with non-Hodgkin's } \\
\text { lymphoma }(\mathrm{n}=3) \\
\text { Humans with renal carcinoma } \\
(\mathrm{n}=15)\end{array}$ & Observation & $\begin{array}{c}100 \% \text { effective, } 1 \\
\text { patient partial } \\
\text { response, } 2 \text { patients } \\
\text { stable disease } \\
40 \% \text { effective, } 1 \\
\text { individual partial } \\
\text { response, } 3 \\
\text { experienced stable } \\
\text { disease } \\
16 \% \text { effective, } 4 \\
\text { patients stable disease } \\
25 \% \text { effective, I } \\
\text { patient patrial } \\
\text { response, } 3 \\
\text { individuals stable } \\
\text { disease }\end{array}$ & $\begin{array}{l}\text { Enhanced CD27 } \\
\text { co-stimulation } \\
\text { can reduce } \\
\text { tumours in } \\
\text { humans }\end{array}$ & $\begin{array}{c}\text { Varlilumab } \\
\text { [Ref. 71] }\end{array}$ \\
\hline
\end{tabular}

